\title{
THE INHERENT RISKS OF HUMAN LEARNING
}

\author{
Paul Smeyers \\ Faculty of Psychology and Educational Sciences \\ Katholieke Universiteit Leuven \\ Pádraig Hogan \\ Education Department \\ National University of Ireland, Maynooth
}

As a distinctive human undertaking, education carries risks that are deep and enduring. It would be true in an everyday sense to say that these risks are often overlooked, or unnoticed. It would be closer to the mark, however, to say that they have been largely domesticated, or even insured against, by the institutional forms education has historically taken, at least in Western civilization. Here, we are clearly not talking about entrepreneurial risks, fueled as these are by the prospects of material profit, though education has more than occasionally been used to promote a sense of individual entrepreneurial spirit. Nor are we talking of the risks an individual might take to achieve fame and glory. Nor yet are we talking of the risks a group of people might take to win human rights or political freedoms. Rather, the risks we are calling attention to here are those that are inescapably — not just contingently - connected with the deliberate promotion of human learning. At stake is nothing less than what we become as human beings as a consequence of what we experience as learners. Such consequences include coming to understand and judge ourselves, our human significance, and our prospects in certain ways rather than in others; coming to understand and judge others and their significance in particular ways; and coming to understand and judge the merits of learning itself in its various forms and possibilities.

For teachers such risks include those of setting themselves and their knowledge forth for examination; of being surpassed, pulled up short, or embarrassed before one's students; of failing despite one's best efforts on behalf of one's students; and of exerting influence on a daily basis in ways that may well have unforeseen or immeasurable consequences. For students the risks include those of possibly failing in their studies, of being rejected by their teachers or fellow students, or of having to endure less-than-inspiring teachers. For parents there are the many risks associated with entrusting their children to a particular school or teacher. For governments there are the risks associated with allowing (or forbidding) educational institutions the freedom to pursue teaching and learning as an endeavor with its own distinctive responsibilities, separate from those of the state, the ruling party, or any other interest group. These examples illustrate that the risks of education are different in nature and scope from the more calculable risks that are encountered in other fields of human endeavor, such as business, engineering, law, or even medicine. 
Plato was among the first and the most influential to suggest that the stakes in education are too high to allow the control and management of this undertaking to be left in the hands of teachers. Arising from his conviction that the independent schools of the sophists had done much to engender a pervasive decadence in Athenian culture, Plato carried out probing and insightful studies into the risks of education. As a result of these efforts, he devised comprehensive educational provisions that sought to rid education of undesirable possibilities and to present it with challenges that were worthy of the efforts of learners and their teachers. ${ }^{1}$ For Plato, the worth of an educational goal depended on whether it was informed by a higher truth, according to his own intricate metaphysical theory. On his view, the conduct of education is best entrusted not to teachers but to a higher authority possessed of such truth: philosopher-rulers.

Despite his concerns about Plato's metaphysics, Aristotle largely agreed with Plato where the control of education was concerned. Notwithstanding the incisiveness and subtlety of his insights into human friendship (philia) and deliberative reasoning (phronesis), Aristotle's views on the conduct of education were forthright and echoed strongly Plato's concern with removing undesirable risks. In his Politics, Aristotle argued that "since the polis as a whole has a single aim, the education of all must be one and the same." To this he added: "the supervision of this education must be public and not private, as it is in the present system, under which everyone looks after his own children privately and gives them any private instruction he thinks proper." Aristotle's justification for such a stance is much more concise than that of Plato and appears in the text of Politics almost as an incidental remark: "Besides, it is wrong for any citizen to think that he belongs to himself. All must be considered as belonging to the polis: for each man is a part of the polis, and the treatment of the part is necessarily determined by the treatment of the whole." ${ }^{2}$

This parallel between Plato and Aristotle is significant for a number of reasons that are pertinent to the essays that follow. First, it marks the surrender of the inherent risks of education to the will of a paternalistic power. Second, it marks a departure from the independent and individualistic, though scarcely less paternalistic, style of the schools of the sophists. Third, it involves a negation, in both style and substance, of something that might otherwise have become a distinctive and

1. Plato, The Republic, trans. Benjamin Jowett, see books II-IV, VI, and VII, http://classics.mit.edu/plato/ republic.html; and Plato, Laws, trans. Benjamin Jowett, see books I, VI, and VII, http://classics.mit.edu/ plato/laws.html.

2. Aristotle, Politics, trans. T.A. Sinclair (London: Penguin, 1981), VIII, 1337a.

PAUL SMEYERS is Professor in the Faculty of Psychology and Educational Sciences at Katholieke Universiteit Leuven, Tiensestraat 102, B-3000 Leuven, Belgium; e-mail <paul.smeyers@psy.kuleuven. ac.be $>$. His primary areas of scholarship are educational theory, Wittgenstein, postmodernism, and qualitative research methods.

PÁDRAIG HOGAN is Professor in the Education Department at National University of Ireland Maynooth, Maynooth, Co. Kildare, Ireland; e-mail <padraig.hogan@nuim.ie>. His primary areas of scholarship are philosophy of education, innovations in teaching and learning, quality in educational experience, and historical perspectives on education. 
vibrant educational inheritance in the West: the venturesome and self-critical kind of learning that the historical Socrates sought to promote, with fellow residents and visitors alike, in the public places of ancient Athens.

Centuries later, once Christianity had become the religion of an empire that for a time included most of Western civilization, the paternalistic rather than the Socratic precedent became the decisive one where education was concerned. That precedent became infused afresh with religious doctrines, however. For the most part these doctrines were not the practical tenets of Christianity as a religion of love and reconciliation; rather, they were doctrines of an ascetic kind, associated with the more severe theological conclusions found in the writings of St. Paul and St. Augustine. And the consequences of such developments were far-reaching indeed. As historians of education have pointed out, an ecclesiastical monopoly became established in "Christendom" for almost a thousand years. Accordingly, the spirit and substance of Western learning became aligned with church doctrines and interests. ${ }^{3}$

In this long history, paternalistic standpoints have been legion. For the sake of clarity, these standpoints can be described collectively as measures that sought to safeguard learners and their teachers from risks deemed undesirable and to impose penalties for embracing such risks. A study of this history reveals, however, that church authorities were themselves rarely free from the risk that some emergent intellectual movement might upset an apparently settled climate of acquiescence or might break apart a dominant orthodoxy. The following examples illustrate a few of the diverse ways in which the risks of learning provoked to critical action both intellect and sensibility among successive generations of learners and teachers. Recall, for instance, the turbulence occasioned in twelfth-century Paris by Peter Abelard's efforts to open for debate among his students questions that ecclesiastical authorities had long regarded as settled. More striking in a practical sense are the fruits that such a questioning kind of learning produced, evident for example in the incisive and spirited letters of the adult Héloise, possibly the best of his former students, to Abelard himself. ${ }^{4}$ Then there are the writings of Erasmus of Rotterdam, most notably Praise of Folly, which sought through devices such as irony, humor, and artifice to point learning in directions more worthy of learners' efforts than those of a prevalent and predictable scholasticism. ${ }^{5}$ And, of course, there are the examples of Luther, Copernicus, Galileo, and countless (less wellknown) others, who were well aware that their various paths of inquiry involved dangerous risks, but who still pursued those paths in the hope that the experience of learning might bring a greater abundance, and fewer restrictions, to succeeding generations.

3. William Boyd and Edmund J. King, The History of Western Education (London: Adam and Charles Black, 1966), 101.

4. Betty Radice, ed., The Letters of Abelard and Heloise (London: Penguin Books, 1999); and Constant J. Mews and Neville Chiavaroli, eds., The Lost Love Letters of Abelard and Heloise (Basingstoke, England: Palgrave Macmillan, 2001).

5. Desiderius Erasmus, Praise of Folly [1515], trans. Betty Radice (London: Penguin Books, 1999). 
In the more secular times that followed the era of Enlightenment and Revolution (English, American, French), figures who rose to eminence in accepting and engaging the inherent risks of education were no less courageous, and no less energetic. For instance, Wilhelm von Humboldt, as Prussian minister for education, accomplished something unprecedented when he established the University of Berlin in 1809-10. Here was an institution that would be maintained by the public purse, would pursue scientific (wissenschaftliche) research as a form of liberal learning, and would be free of state control. In challenging both the authoritarian legacies of the Prussian monarchy and the reality of Napoleonic imperial power, Humboldt boldly envisaged the new institution as a center of academic freedom and as the "mother of all modern universities." A similar hope and boldness is evident in Thomas Jefferson's efforts to establish a nondenominational university in the United States, the University of Virginia. In a letter to William Roscoe, dated December 27, 1820, he declared that "this institution will be based on the illimitable freedom of the human mind. For here we are not afraid to follow truth wherever it may lead, nor to tolerate any error so long as reason is left free to combat it. ${ }^{\prime \prime}$

Of course Humboldt's university, and the many that were later modeled on it, often fell short of the lofty ideals of their founders. And it took more than a little time for the "freedom of the human mind" at the University of Virginia to lead it to the point of acknowledging that female and black students should be admitted on the same basis as white male students. Although many might regard these shortcomings as signs of failure, it is more instructive to understand them as sobering pieces of historical evidence that also suggest something of acute philosophical and educational significance: Perhaps the risks of education that are most worth taking are those that humanely bring to light undetected but invidious preconceptions and that enable learning in any field to proceed as a distinctively human endeavor with a perceptive sense of its own possibilities and limitations. The taking of such risks in a responsible way would thereby reclaim something genuinely Socratic. It would seek to deepen our awareness of the reciprocal nature and the illimitable scope of the work that education itself must attempt. This clearly distinguishes the enduring interests of education from the interests of politics, or religion, or commerce.

No less than their ecclesiastical predecessors in Western Christendom, the secular educational authorities of very many Western democracies find it difficult to acknowledge this important distinction. For these contemporary authorities, however, the risks that are to be kept at bay, and those that are to be encouraged, reveal the rise to dominance of a different kind of orthodoxy, one that places its strongest faith in various forms of managerial prowess. On this orthodoxy, the managers of educational institutions are charged by their political masters with ensuring that each student's progress will be regularly ascertained by the use of objective tests; that each school's performance on such tests will be made public

6. Thomas Jefferson to William Roscoe, December 27, 1820, http://www.monticello.org/reports/quotes/ uva.html. 
as an index of success or failure, so as to enable parents a clear basis for choosing among schools; that schools will have built-in systems to make them effective learning organizations; that schools will make sure that the learning efforts of students complement the top priorities of social and economic policy; and that institutions of higher learning will align their efforts to the requirements of economic and technological advance.

A strong argument can be made that the purposes just listed are worthy of public support in a democratic society. Such concerns as providing adequate appraisal of students' accomplishments, ensuring accountability to the public, developing valid procedures for the evaluation and improvement of educational practice, embodying justice and equity in the provision of educational opportunities, identifying and providing for students' vocational potentials, and making decisive contributions to a country's economic well-being clearly mark important dimensions of education as a public concern. But they do not encompass the heart of education; indeed, they contribute to a displacement of that heart, to a disfigurement of education itself, when they regard it as a system in which certain risks (the inherent uncertainties of education) should be minimized while a capacity for other kinds of risk-taking (individualistic-entrepreneurial) should be promoted. Moreover, this problem is compounded where technocratic thinking furnishes an elaborate machinery of management that educational authorities can deploy - earnestly or otherwise - at the pleasure of the current government in power. As a number of the following essays show, the field of higher education internationally has become a particular casualty of such displacement. The public purposes of education achieve a decidedly different significance, however, if they are engaged and pursued in a hospitable context - that is, a context in which what we have called the enduring interests of education are clearly acknowledged as a distinct public office or field of endeavor. But then a certain measure of risk must be tolerated, even embraced.

The reluctance, or refusal, of so many governments to grant unambiguous recognition to such an office could be described as a lingering disappointment of one of the chief hopes of the Enlightenment. Currents of thinking that run from Rousseau through Kant and Humboldt to Dewey conceive of education as an emancipation from traditional custodianships of intellectual sensibility and as a pathway to human flourishing, both personal and social. And clearly we have become accustomed to a wide range of rights and liberties that would have been no more than idealistic hopes in premodern times. Yet, the Greek-Roman-ecclesiastical conception of education as an office that is essentially subordinate to the will of a higher institutional authority has endured. The occupants of the seats of power in such higher authorities have changed, as have the things that are to be regarded as risks. But despite many generations of transition since the high Enlightenment, the basic conception of education as an instrument of such authority survives. More significantly, in a postmodern age, the incarnation of this idea is more mercenary than religious. Accordingly, against the newer form of educational orthodoxy, the possibilities offered by Friedrich Nietzsche strike many, including some of the authors 
of the contributions here, as particularly incisive. Nietzsche's themes of the positive appreciation of suffering and endurance, of übermensch as a form of responsibility that withstands and confronts a prevalent nihilism but without subjective/ heroic overtones, and of taking seriously the depths of ignorance that are the dark side of unprecedented knowledge are just a few examples of such possibilities.

In any case the essays that follow provide revealing explorations of how the risks of human learning are conceived today and of how the power of the higher institutional authorities that seek to control education is currently exercised. The purpose of these explorations is not to disclose the unhappiness of education's current lot. Undoubtedly, the following analyses highlight much that is amiss with prevailing approaches to shaping and implementing educational policies in many Western countries. But their main purpose is to heighten awareness that educational practice is sustained and renewed by an inspired human commitment and to identify some forms of thought and action that are most worthy of such commitment.

In the opening contribution Michael Peters draws on the work of Ulrich Beck, for whom the historically important transition is not from industrial society to postindustrial or postmodern society, but to "risk society." ${ }^{17}$ In this context the driving logic is no longer class politics as an organizing principle but rather socially manufactured risk and risk management. Such a "risk society" is put in place through actuarial mechanisms, and it emphasizes the importance of all types of insurance as a means of reducing risk to the individual (in such areas as employment, education, accident, security, and retirement). The regulation of risk takes place through insurance and the "responsibilization" of the individual consumer. Peters calls this phenomenon a prudentialization of social regulation and explores the strategic role educational policy has played in advancing it.

Richard Smith's contribution also concentrates on the critical purposes of the university. According to Smith, the manner in which the modernist quest for equity and efficiency is pursued drives contingency and meaningful educational risk from the university. Along with these much else disappears: chiefly, the possibility of a relation between teacher and taught that may be the basis for realizing forms of human freedom that otherwise cannot be realized, or perhaps even imagined. Such freedoms, Smith argues, are associated with live and autonomous teachers, as distinct from interactive learning packages. And to acknowledge this in practice, he points out, involves a considerable risk - that of exposing what one loves to scrutiny and perhaps rejection. To eliminate such vulnerability from education, Smith concludes, is to abandon education itself for a counterfeit.

Stefan Ramaekers investigates the "empowerment" approach that has now become almost a commonplace of educational correctness. He shows how this conception of educational support for families, because of the very language in which it is framed (parent-as-participant, educator-as-facilitator), is one-sided. It invites the mistaken idea that the professional educator seeks, and should seek, to assume an attitude of abstinence. Ramaekers argues that the educator must speak - must

7. Ulrich Beck, Risk Society: Towards a New Modernity (London: Sage, 1992). 
own his or her voice and embrace the risks of venturing it - in order to elicit those voices ("e-vocation") that might otherwise remain inarticulate or disabled. This, he shows, is not "speaking on behalf of others" but helping others to discover which among the many internal voices vying for expression are ones for them to own here and now.

Paul Smeyers deals with the illusion that "theory" creates in education: that problems can be solved once and for all, and that matters can thus be made more "manageable." His investigation into the nature of theories (both quantitative and qualitative) in empirical research leads him to argue that the best theory can do is illuminate particulars, as distinct from discovering something universal. Ignoring the particularities of educational practice, he points out, puts at risk the kind of thinking that is most appropriate to understanding that practice itself. He suggests that philosophy of education has hardly been more effective in this regard than have theories in empirical research. Ultimately, Smeyers concludes that, instead of being neutral or only looking for presuppositions, anything that is to count as educational theory should show how things "have to be." This involves the inescapability of offering a particular stance, a particular judgment, a commitment to this or that in life.

Pádraig Hogan addresses two tendencies in his essay: first, the tendency of premodern forms of authority to domesticate or otherwise control human learning as a search for truth; and, second, the postmodern tendency to eschew that search itself as misguided. Hogan argues that if the search for truth is discarded as a purpose of learning, then something irreplaceable is undermined from the start namely, the integrity of learning itself as a worthy and enduring, but essentially risky, undertaking. His position is that in order to understand human learning as a search for truth, one must abandon the hope of attaining a complete metaphysical picture or epistemologically secured certainty. Rather, it is to experience firsthand the endless interplay of limitation and promise within the search itself. To engage in such action, Hogan concludes, is to be enjoined to practice this search afresh with others in a way that is both venturesome and critically disciplined, a way that acknowledges, and learns amid, the plurality of human perspectives. 